\title{
Homology modeling, structure and active site prediction of stem rust resistant gene Sr22 in wheat cultivars
}

\author{
Shahzad Bashir ${ }^{1 *}$, Shazia Anwer Bukhari ${ }^{1}$, Mahmood-ur-Rahman² and \\ Muhammad $\mathrm{Ali}^{3}$ \\ 1. Department of Biochemistry, Government College University, Faisalabad, Allama Iqbal Road, Faisalabad- \\ 38000-Pakistan \\ 2. Department of Bioinformatics and Biotechnology, Government College University, Faisalabad, Allama Iqbal \\ Road, Faisalabad-38000-Pakistan \\ 3. Department of Zoology, Government College University, Faisalabad, Allama Iqbal Road, Faisalabad-38000- \\ Pakistan \\ *Corresponding author's email: bukhari.shazia@yahoo.com \\ Citation
}

Shahzad Bashir, Shazia Anwer Bukhari, Mahmood-ur-Rahman and Muhammad Ali. Homology modeling, structure and active site prediction of stem rust resistant gene Sr22 in wheat cultivars. Pure and Applied Biology. Vol. 8, Issue 1, pp553-558. http://dx.doi.org/10.19045/bspab.2018.700216

\begin{tabular}{llll}
\hline \hline Received: 27/10/2018 & Revised: 13/12/2018 & Accepted: 18/12/2018 & Online First: 21/12/2018 \\
\hline \hline
\end{tabular}

\section{Abstract}

Protein structure and function is very important to study before gene transformation. Protein homology modeling is very important tool used to predict the structure of the protein. Sr22 gene codes for a Sr22 protein which confers resistance against Puccinia graminis. The homology modeling of Sr22 protein was obtained by using SWISS-MODEL web tool. Then the predicted model of Sr22 protein was superimposed to check the validation through errat. Errat score for this model was $77 \%$ which was further improved up to $80 \%$ by doing loop optimization of $\operatorname{Sr} 22$ using similar tool. 3D model of stem rust resistant protein was further used to analyze the activity of the protein. Active sites of $\mathrm{Sr} 22$ protein were detected by using ADDS (Automated active sites detection, docking and scoring) software. Total of 17 active sites were identified and active sites with the highest score were used in further studies. The information achieved may be useful to understand the mechanism resistance to stem rust disease in wheat which may further help to manipulate for sustainable resistance.

Keywords: Active site prediction; Homology Modeling; Puccinia graminis; Sr22 protein; Stem Rust

\section{Introduction}

Puccinia graminis f. spp. Tritici Pers. causes stem rust disease in wheat crop. Sr22 is a gene that provides resistance against the fungus. This disease has the potential to destroy the whole crop and is an immediate threat to world wheat production. [1]. The Sr22 gene was first discovered in diploid wheat species Triticum monococcum [2] but during the course of evolution from diploid to hexaploid, this gene was lost. It was incorporated into tetraploid and hexaploid wheat through interspecific hybridizations and in commercial varieties by breeding. Sr22 is resistant against Puccinia graminis but it also lowers the yield and delays in 
heading date due to some other genes associated with the $T$. monococcum ssp. boeoticum chromosome segment carrying $\mathrm{Sr} 22$. This drawback has limited its use in breeding $[3,4]$.

$\mathrm{Sr} 22$ is reported in diploid wheat cultivars. It is a large gene having a size of $2823 \mathrm{bp}$ of the coding region. Before the introduction of $S r 22$ gene in commercial wheat from the wild genome of diploid wheat, it is necessary to understand the product of the gene and the pathways in which it is involved. Bioinformatics tools are the best sources to understand the function and behavior of the Sr22 protein. This article aimed to model the Sr22 protein and predict its active binding sites in silico. The information achieved will be used to identify the appropriate effectors for $\mathrm{Sr} 22$ protein first in silico and then in vitro [5].

\section{Material and methods}

\section{Sequence retrieval}

The sequence of $\mathrm{Sr} 22$ protein was retrieved from the NCBI sequence database (Accession \# LN883752.1).

\section{Protein homology modeling}

Homology modeling of Sr22 proteins was done by using SWISS-MODEL web bioinformatics tool (https://swissmodel.expasy.org/). It is a web tool used for the homology modeling of protein three-dimensional structure [6].

\section{Model evaluation}

The 3D model of $\mathrm{Sr} 22$ protein was evaluated by ERRAT. This model helps to analyze the statistics of non-bonded interactions among types of atom. This model also facilitates to plot the value of the error function versus position of a 9-residue sliding window. All these results were obtained by comparing values with statistics originated from highly refined structures [7].

Active site prediction

ADDS (Automated active sites detection, docking and scoring) was used to predict active sites [8] of Sr22 protein. The accuracy of this software was checked by the molecules of known active sites.

\section{Result and discussion}

\section{Protein model}

The homology modeling of Sr22 protein of wheat (Triticum aestivum), which is encoded by stem rust resistant gene $\mathrm{Sr} 22$ was done by SWISS-MODEL [9]. The model was constructed using the amino acid sequence as a template for $\mathrm{Sr} 22$ protein. Five models were generated and the model with maximum GMQE (Global Model Quality Estimation) was selected as the best model (Figure $1 \&$ Table 1).

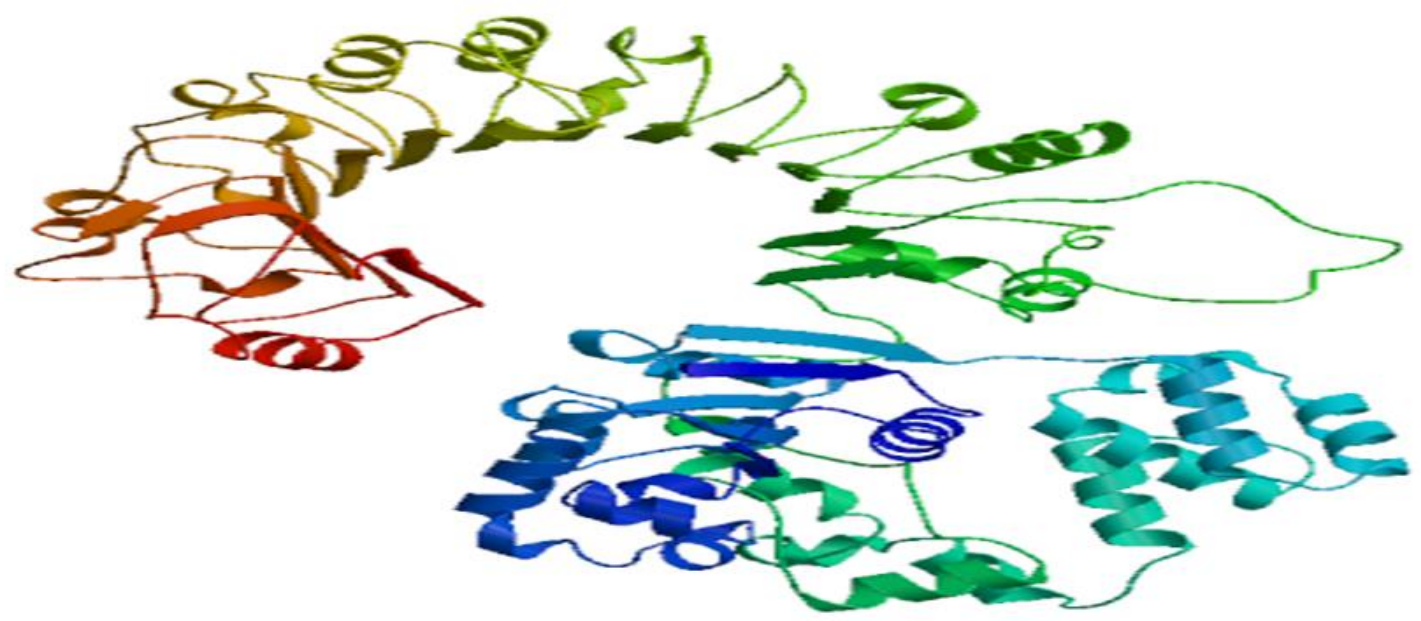

Figure 1. Three- dimensional protein structure of Sr22 best predicted by SWISS-MODEL 
Table 1. Five best models of Sr22 protein predicted by SWISS-MODEL with their quality parameters

\begin{tabular}{|c|c|c|c|c|c|}
\hline Model \# 01 & Model & Oligo-State & Ligands & GMQE & QMEAN \\
\hline 1 & 存 & monomer & None & 0.34 & -6.43 \\
\hline 2 & & $\begin{array}{c}\text { monomer (matching } \\
\text { prediction) }\end{array}$ & None & 0.20 & -7.17 \\
\hline 3 & & $\begin{array}{l}\text { monomer (matching } \\
\text { prediction) }\end{array}$ & None & 0.20 & -8.21 \\
\hline 4 & 冬以樶 & monomer & None & 0.16 & -7.27 \\
\hline 5 & so de & monomer & None & 0.15 & -6.80 \\
\hline
\end{tabular}

Model Evaluation

The selected best model was evaluated by ERRAT. The best model score of $\mathrm{Sr} 22$ protein was $77 \%$. The score was further improved up to $80 \%$ by doing loop optimization of $\mathrm{Sr} 22$ protein using a similar tool (Figure 2).

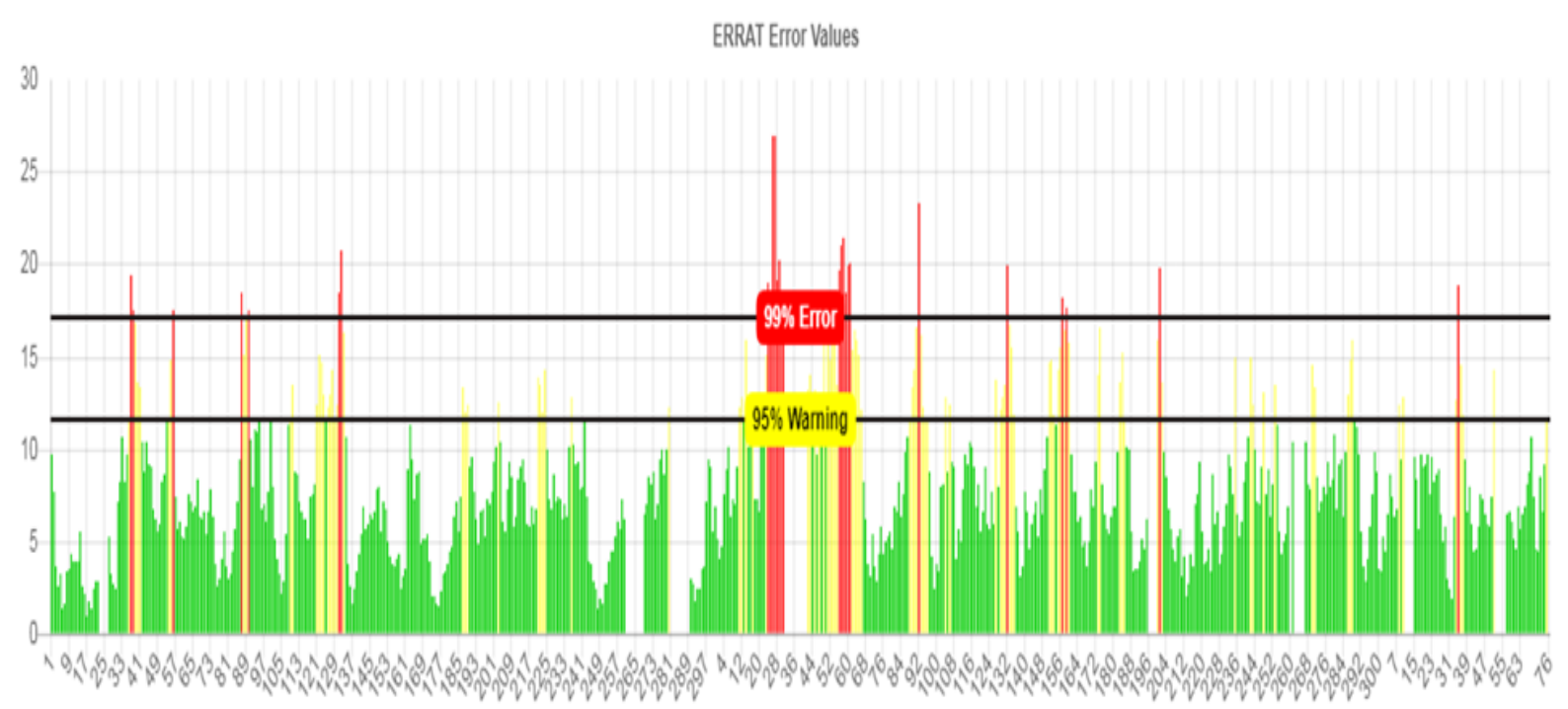

Residue \# (window center)

Figure 2. Validation of a predicted model of $\mathrm{Sr} 22$ protein by ERRAT software 


\section{Active site prediction}

Active sites of wheat $\mathrm{Sr} 22$ protein was predicted using ADDS (Automated active sites detection, docking and scoring) [10]. Total of 37 cavities were predicted initially but the only one pocket with the highest score was selected for further analysis (Figure 3).

The Sr22 protein haplotype of PI 306540 carries the same amino acids as the resistant alleles at three of the four positions that discriminate the resistant and susceptible Sr22 protein haplotypes. There are 8 polypeptide binding interaction sites in the protein $(75,79,82,111,114,117-119,121$ 123 and 125-126) (Table 2).

$\mathrm{Sr} 22$ gene is a high potential rust resistant gene but unfortunately very less studied. Its functions are still unknown [12]. Only one domain is matched with an existing protein database. On the other hand, this protein has 7 Leucine-rich regions and 8 binding sites which make it highly effective against the Puccinia graminis. Leucine-rich regions are known to identifying the fungus proteins and activate the defense mechanism [13].

The binding sites have the ability to bind with GTPase Activating Protein 2 (RanGAP2). Initially, RanGAP2 was identified as a regulator of cell division and nucleocytoplasmic trafficking. Later it was discovered that it also plays an important role in interacting with the Coiled-Coil domain [14]. Coiled-Coil domain is a structural motif in protein in which 2 to 7 alpha helix structures of protein coiled together to make a rope-like structure [15]. Sr33 another gene of this family that confirms the resistance against wheat stem rust also has such CoiledCoil domain. This Coiled-Coil domain presence in $\mathrm{Sr} 33$ predicts that $\mathrm{Sr} 22$ will also have to confirm resistance against Puccinia graminis [16].

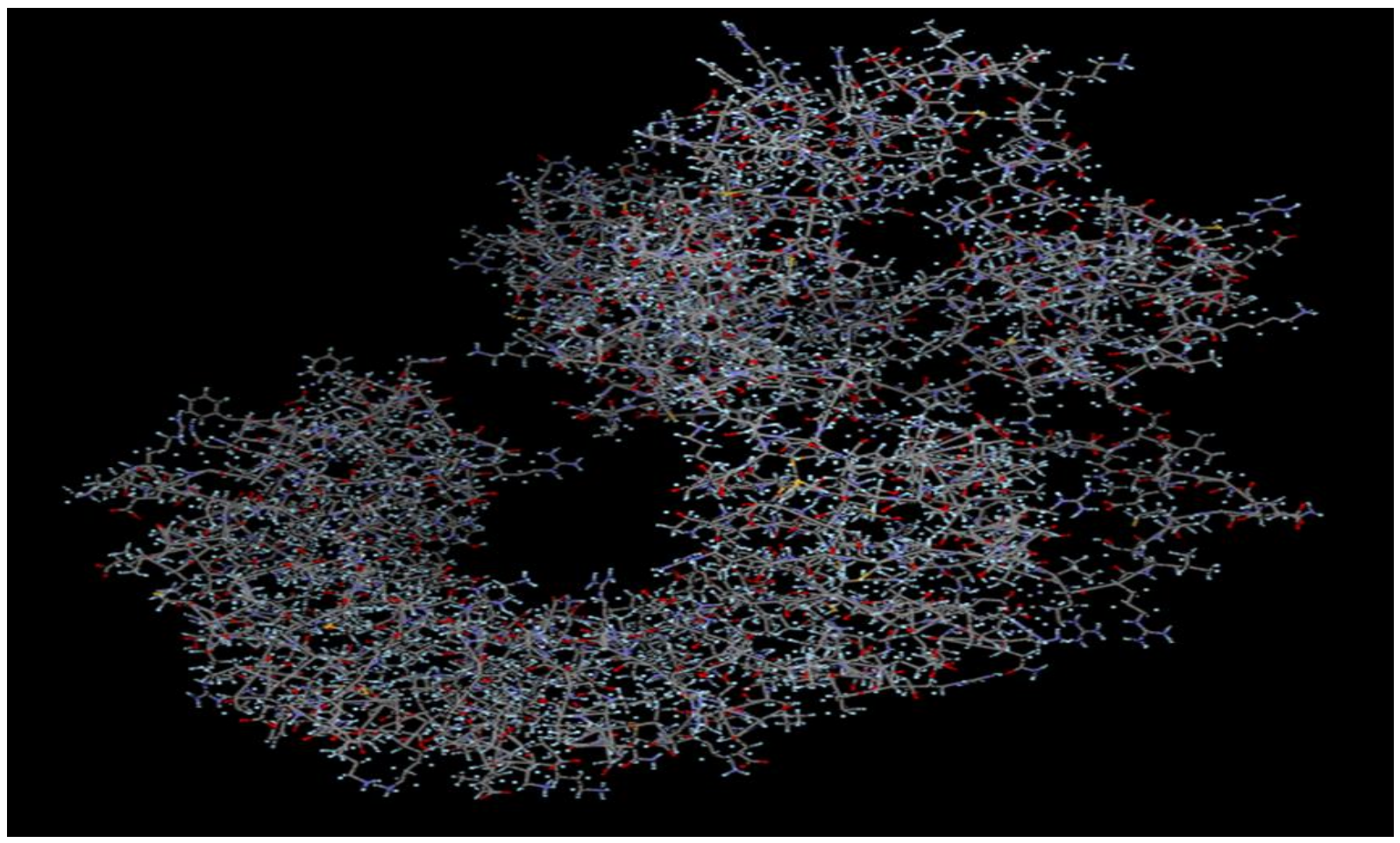

Figure 3. The three-dimensional structure of active sites of $\mathrm{Sr} 22$ protein generated by AADS tool. The different colors show different atoms as a white color for carbon, blue for nitrogen, red for oxygen purple for hydrogen 
Table 2. Sr22 protein with function associated sites [11]

\begin{tabular}{|c|c|c|c|}
\hline Sr. No & Regions & Location & Function \\
\hline 1 & Coiled-coil domain & $11-139$ & Resistant domain \\
\hline 2 & polypeptide binding & 75 & RanGAP2 interaction site \\
\hline 3 & polypeptide binding & 79 & RanGAP2 interaction site \\
\hline 4 & polypeptide binding & 82 & RanGAP2 interaction site \\
\hline 5 & polypeptide binding & 111 & RanGAP2 interaction site \\
\hline 6 & polypeptide binding & 114 & RanGAP2 interaction site \\
\hline 7 & polypeptide binding & $117-119$ & RanGAP2 interaction site \\
\hline 8 & polypeptide binding & $121-123$ & RanGAP2 interaction site \\
\hline 9 & polypeptide binding & $125-126$ & RanGAP2 interaction site \\
\hline 10 & NB-ARC domain & $176-458$ & \\
\hline 11 & Leucine-rich repeat (LRR) & $<524->727$ & $\begin{array}{c}\text { Provide recognition of pathogen products } \\
\text { of avirulence (AVR) genes }\end{array}$ \\
\hline 12 & Leucine-rich repeat (LRR) & $567-597$ & $\begin{array}{c}\text { Provide recognition of pathogen products } \\
\text { of avirulence (AVR) genes }\end{array}$ \\
\hline 13 & Leucine-rich repeat (LRR) & $598-620$ & $\begin{array}{c}\text { Provide recognition of pathogen products } \\
\text { of avirulence (AVR) genes }\end{array}$ \\
\hline 14 & Leucine-rich repeat (LRR) & $621-641$ & $\begin{array}{c}\text { Provide recognition of pathogen products } \\
\text { of avirulence (AVR) genes }\end{array}$ \\
\hline 15 & Leucine-rich repeat (LRR) & $642-662$ & $\begin{array}{l}\text { Provide recognition of pathogen products } \\
\text { of avirulence (AVR) genes }\end{array}$ \\
\hline 16 & Leucine-rich repeat (LRR) & $725-769$ & $\begin{array}{l}\text { Provide recognition of pathogen products } \\
\text { of avirulence (AVR) genes }\end{array}$ \\
\hline 17 & Leucine-rich repeat (LRR) & $770-793$ & $\begin{array}{c}\text { Provide recognition of pathogen products } \\
\text { of avirulence (AVR) genes }\end{array}$ \\
\hline
\end{tabular}

\section{Conclusion}

The advantage of this study is that the gene $\mathrm{Sr} 22$ is itself present in the wheat genome in old and wild cultivars. So there is a possibility of no issues with the metabolites of the transgenic plant as compared to nontransgenic except the protein of $S r 22$.

\section{Authors' contributions}

Conceived and designed the experiments: S Bashir \& SA Bukhari, Performed the experiments: $S$ Bashir, Analyzed the data: $S$ Bashir, SA Bukhari \& MU Rahman, Contributed materials/ analysis/ tools: SA Bukhari, MU Rahman \& M Ali, Wrote the paper: S Bashir.

\section{References}

1. Olson EL, Brown-Guedira G, Marshall D, Stack E, Bowden RL, Jin Y \& Pumphrey MO (2010). Development of wheat lines having a small introgressed segment carrying stem rust resistance gene Sr22. Crop Sci 50(5): 1823-1830.

2. Gerechter-Amitai ZK, Wahl I, Vardi A \& Zohary D. (1971). Transfer of stem rust seedling resistance from wild diploid einkorn to tetraploid durum wheat by means of a triploid hybrid bridge. Euphytica 20(2): 281-285.

3. Yu LX, Liu S, Anderson JA, Singh RP, Jin Y, Dubcovsky J \& Huerta-Espino J (2010). Haplotype diversity of stem rust resistance loci in uncharacterized wheat lines. Mol Breeding 26(4): 667-680.

4. Jin Y, Singh R, Ward R, Wanyera R, Kinyua M, Njau $\mathrm{P} \&$ Yahyaoui A. (2007). Characterization of seedling infection types and adult plant infection responses of monogenic Sr gene lines to race TTKS of Puccinia graminis f. sp. tritici. Plant Dis 91(9): 1096-1099. 
5. Bukhari SA, Mahmood-Ur-Rahman, Shamshari WA \& Bashir S (2018). Homology Modeling, Structure and Active Site Prediction of Stem Rust Resistant Protein in Wheat. Mol Biol 411-414

6. Arnold K, Bordoli L, Kopp J \& Schwede $T$ (2006). The SWISS-MODEL workspace: a web-based environment for protein structure homology modelling. Bioinform 22(2): 195-201.

7. Colovos C \& Yeates TO. 1993. Verification of protein structures: patterns of nonbonded atomic interactions. Protein Sci 2(9): 15111519.

8. Singh T, Biswas D \& Jayaram B. (2011). AADS-An automated active site identification, docking, and scoring protocol for protein targets based on physicochemical descriptors. Journal of chemical Inform and Modeling 51(10): 2515-2527.

9. Schwede T, Kopp J, Guex N \& Peitsch MC (2003). SWISS-MODEL: an automated protein homology-modeling server. Nucleic Acids Res 31(13): 33813385.

10. Briggs J, Chen S, Zhang W, Nelson S, Dubcovsky J \& Rouse MN (2015). Mapping of SrTm4, a recessive stem rust resistance gene from diploid wheat effective to Ug99. Phytopathol 105(10): 1347-1354.

11. Chen S, Guo Y, Briggs J, Dubach F, Chao S, Zhang W \& Dubcovsky J.
(2018). Mapping and characterization of wheat stem rust resistance genes $\mathrm{SrTm} 5$ and $\quad \operatorname{Sr} 60$ from Triticum monococcum. Theoretical and Appl Genet 131(3): 625-635.

12. Zhang M \& Coaker G. (2017). Harnessing effector-triggered immunity for durable disease resistance. Phytopathol 107(8): 912-919.

13. Shanmugam V (2005). Role of extracytoplasmic leucine rich repeat proteins in plant defence mechanisms. Microbiol Res 160(1): 8394.

14. Carpentier J, Grenier E, Esquibet M, Hamel LP, Moffett P, ManzanaresDauleux MJ \& Kerlan MC (2013). Evolution and variability of Solanum RanGAP2, a cofactor in the incompatible interaction between the resistance protein GPA2 and the Globodera pallida effector Gp-RBP1. BMC Evolutionary Biol 13(1): 87.

15. Liu J, Zheng Q, Deng Y, Cheng CS, Kallenbach NR \& Lu M (2006). A seven-helix coiled coil. Proc of the National Acad of Sci 103(42): 1545715462.

16. Casey LW, Lavrencic P, Bentham AR, Cesari S, Ericsson DJ, Croll T \& Mobli M (2016). The CC domain structure from the wheat stem rust resistance protein $\mathrm{Sr} 33$ challenges paradigms for dimerization in plant NLR proteins. Proc of the National Acad of Sci 113(45): 12856-12861. 